\title{
Spatial and Temporal Resource Use by Dominant Benthic Amphipoda (Ampeliscidae and Corophiidae) on the Middle Atlantic Bight Outer Continental Shelf
}

\author{
Linda C. Schaffner and DonaId F. Boesch *** \\ Virginia Institute of Marine Science and School of Marine Science, The College of William and Mary, Gloucester Point, \\ Virginia 23062, USA
}

\begin{abstract}
The study was designed to investigate ecological relationships among numerically dominant species of amphipods in the families Ampeliscidae and Corophiidae on the outer continental shelf of the Middle Atlantic Bight, USA. It assesses the importance of biotic interactions by examining spatial and temporal patterns in abundance and distribution. A complex set of physical and biological factors govern distribution and abundance of these species within the outer shelf zone. In outer shelf swale (topographic depression) habitats the ampeliscid Ampelisca agassizi effectively excludes other members of the family. This may be the result of the species' superior ability to utilize spatial resources. Outside of swale habitats the abundances of the ampeliscids Ampelisca vadorum and Byblis serrata may be limited by the availability of trophic resources. The corophiids exhibited little evidence of resource partitioning. Some differences in microhabitat distribution may facilitate coexistence of the species in this family, as well as between families. The corophiids Unciola irrorata and Erichthonius rubricornis are known to comprise a major portion of the diet of benthic fishes on the outer shelf. It is suggested that populations of these species may be held below the levels at which biotic interactions become important by both benthic predators and physical disturbance.
\end{abstract}

\section{INTRODUCTION}

Identifying the factors responsible for species coexistence in communities is a major focus of ecology. In the marine environment the structuring roles of both competitive interactions and predation have been documented for hard- and soft-substrate benthic communities. A number of studies have shown that competition for space in the rocky intertidal zone can lead to spatial monopoly by the competitively superior species (Connell, 1961; Stimson, 1970; Dayton, 1971). Competition for trophic resources among motile pre-

\footnotetext{
- A portion of a thesis (LCS) submitted in partial fulfillment of the Masters degree, School of Marine Science, College of William and Mary, Gloucester Point, Virginia, USA.

- Contribution No. 1063 from the Virginia Institute of Marine Science

-. Present address: Louisiana Universities Marine Consortium, Marine Research and Education Center, Cocodrie, Louisiana, USA
}

dators in hard-substrate systems has also been documented (Menge, 1972; Menge and Menge, 1974). In many of these studies, and numerous others (e. g. Paine, 1966, 1969, 1974; Dayton, 1971; Menge and Sutherland, 1976; Lubchenco and Menge, 1978) predation has been shown to mediate competitive interactions by maintaining low densities of species potentially limited by the same resources.

It has been more difficult to identify clearly the factors which facilitate species coexistence and maintain organization in soft-substrate benthic communities. The observed partitioning of potentially limiting resources among species in many of these communities supports the contention that a competitive structuring mechanism is involved (Schoener, 1974; Woodin, 1974; Ivester, 1980; Whitlatch, 1980). Additionally, predation has been increasingly identified as an important mechanism structuring communities, particularly in shallow subtidal and intertidal habitats (Peterson, 1979). 
Amphipods in the families Ampeliscidae and Corophiidae comprise a major portion of the Peracarida, the numerically dominant crustacean taxon on the Middle Atlantic outer continental shelf (Boesch, 1979a). They also are among the most important prey items for juvenile bottom feeding fishes (Edwards, 1976; Boesch, in press). Understanding the mechanisms facilitating coexistence among these tubicolous, surface feeding amphipods would increase our knowledge of the fundamental processes structuring soft-substrate communities. This study was designed to investigate the ecological relationships among these species, and to assess the importance of biotic interactions, by examining spatial and temporal patterns in abundance and distribution. An examination of feeding habits and functional morphologies of the species considered herein will be treated separately (Schaffner, in prep.).

\section{STUDY AREA}

The study area is a region of the Middle Atlantic Bight outer continental shelf (depth 50 to $100 \mathrm{~m}$ ) off New Jersey, designated Area B in a larger study by Boesch (1979a) (Fig. 1). The study site and most of the Middle Atlantic continental shelf is topographically complex as a result of both historic and contemporary geological processes. Tiger Scarp (Fig. 1) is a prominent feature of the eastern portion of Area $B$ and is thought to be an erosional feature marking shoreline position during a major sea level stillstand during Holocene transgression (Milliman, 1973). Below the scarp a series of linear sand ridges trending roughly northeast to southwest further increases the topographic complexity. These major ridges on the outer New Jersey shelf have an average spacing of $6.1 \mathrm{~km}$ and a relief of $6.0 \mathrm{~m}$ from crest to swale (Duane et al., 1972; Swift et al., 1972). It is thought that these linear ridges were generated at the shoreface and later stranded by transgressing seas (Swift et al., 1972; Swift, 1975). Contemporary hydrodynamic processes may be responsible for their further modification and maintenance (Duane et al., 1972; Swift et al., 1972; Stubblefield et al., 1975; Stubblefield and Swift, 1976).

\section{METHODS}

Stations representative of 5 different sedimentary habitats related to shelf topography were sampled quarterly The stations represented deep flank (B1), ridge (B2), deep swale (B3), terrace (B4), and shallow swale (B5) habitats. Stations B1 to B4 were sampled quarterly for 2 yr (November 1975 through August
1977), while Station B5 was sampled quarterly for $1 \mathrm{yr}$ (November 1976 through August 1977). Additionally, 48 samples were collected in the study area based on a stratified random sampling scheme during November 1976. The area was first divided into 6 habitat strata based on a priori data concerning sediment grain size as well as detailed bathymetric charts developed by the U.S. Geological Survey (Knebel and Spiker, 1977). Sampling positions within each stratum (Fig. 1) were then determined by random selection of two Loran $\mathrm{C}$ coordinates. Six replicate $0.1 \mathrm{~m}^{2}$ Smith-McIntyre grab samples were collected during each season at Stations $\mathrm{B} 1$ to $\mathrm{B5} ; 1$ sample was collected at each of the stratified random stations. Following the removal of small cores for sediment and organic carbon analyses, samples were sieved through $0.5 \mathrm{~mm}$ mesh screen, narcotized in $\mathrm{MgCl}_{2}$ and preserved in $10 \%$ buffered formalin.

Sediment grain size distribution was determined by wet-sieving to separate silt-clay and gravel fractions followed by measuring of sand size distribution by rapid sediment analyzer. Total organic carbon content of surface sediment was measured by infrared analyzer (Oceanography International Carbon Analyzer) following heated $\left(125^{\circ} \mathrm{C}\right)$ oxidation by phosphoric acid.

The amphipods utilized in this study - including the ampeliscids Ampelisca agassizi, A. vadorum, Byblis serrata, and corophiids Unciola irrorata, U. inermis and Erichthonius rubricornis - were sorted from samples, enumerated and stored in $70 \%$ ethanol.

Multivariate analyses were employed after preliminary examination indicated that amphipod distribution patterns within the study were not obviously related to any single environmental parameter. Numerical classification was used to group collections from 47 stratified random stations and the November 1976 quarterly collections (mean abundances) on the basis of abundance of the 6 species in those samples. The collection from Station D8 contained none of the species and was, therefore, not included in the analysis. In actuality, 7 taxa were considered in the classification since juvenile Unciola (individuals $\leq 3 \mathrm{~mm}$ could not be identified to species) were considered separately.

Log-transformed $\left(\log _{10} x+1\right)$ species counts (adjusted to comparable surface areas) were used to calculate Bray-Curtis similarity measures for each pair of stations. Both group-average and flexible sorting strategies were used to cluster the stations (Clifford and Stephenson, 1975; Boesch, 1977). The cluster intensity coefficient in the flexible sorting strategy was set at -0.25 which effects moderately intense clustering (Boesch, 1977). Some collections in which amphipods were of low abundances showed low similarities to other collections. Some of these samples 
could be subjectively allocated to groups formed in the cluster analysis based on the proportional abundance of species in the collection.

The magnitude of contribution of each species to the definition of collection groups was estimated by comparing geometric mean abundances within each group of stations and through the use of the F-statistic as an indicator of the among-groups to within-groups variation (log-transformed abundances) (Green and Vascotto, 1978). Species which are primarily limited to one habitat and show little variability within this habitat display high F-ratios, while those species exhibiting low fidelity to any particular habitat or exhibiting a high degree of population variability within habitats display low F-ratios.

Multiple discriminant analysis is a procedure which maximizes the ratio of among-groups to within-groups sums of squares. (Rao, 1952; Cooley and Lohnes, 1962, 1971). The technique was used to identify the abiotic factors most strongly related to the biotically-based collection groupings and therefore to patterns of species abundance within the study area. The tech-

Fig. 1. Location of stations in Area B in relation to bathymetry. Inset: location of study area on Middle Atlantic continental shelf, USA

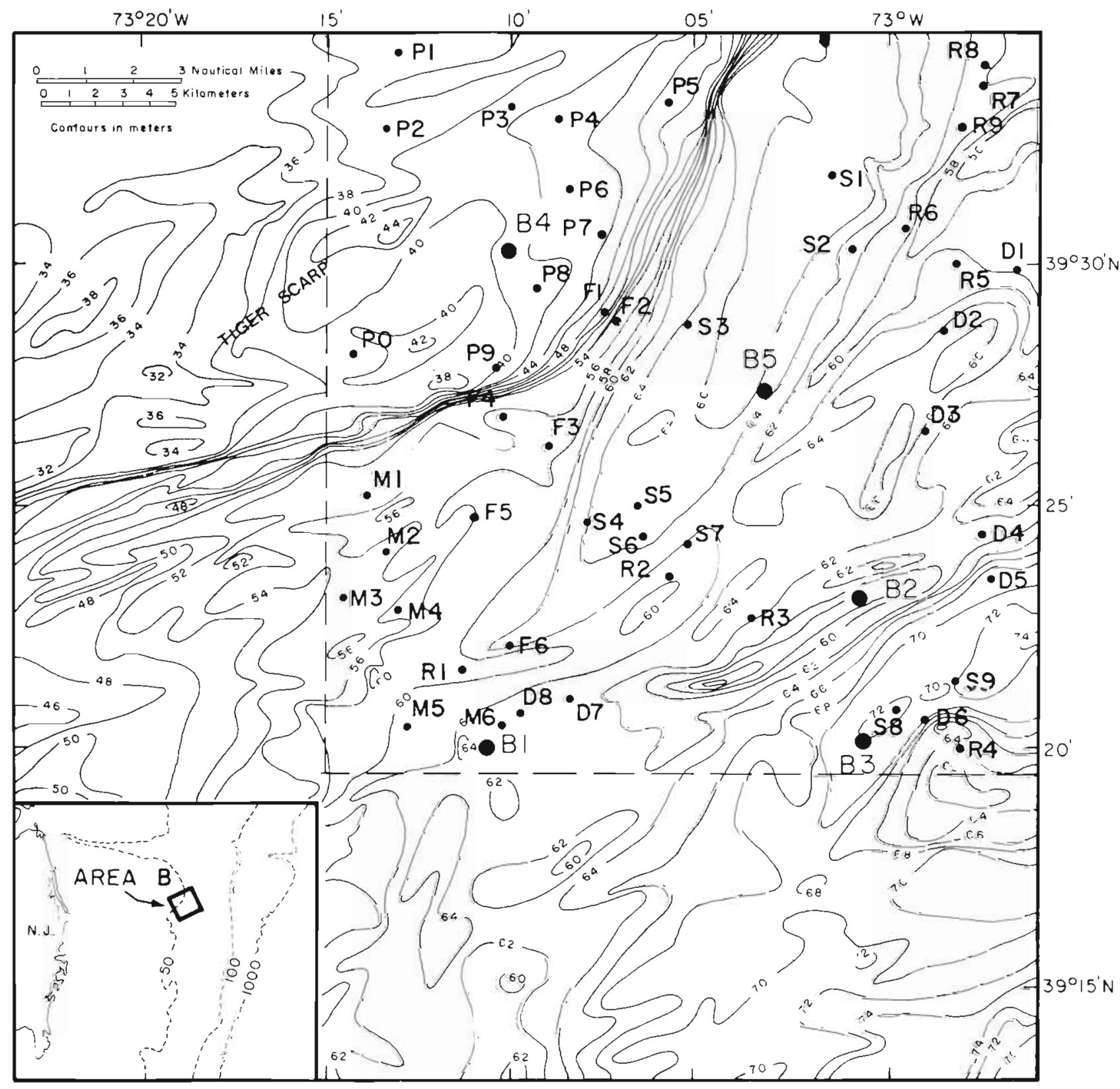


nique simplifies the modeling and analysis of amonggroup differences by producing a reduced-rank model of group distribution in multivariate space. In the reduction from $m$ to $k$ dimensions any parameters that are highly correlated, invariant, or irrelevant to group separation are combined or eliminated (Green, 1971).

Abundance data from quarterly stations were used to determine if the 6 species exhibited strong seasonal trends in abundance which could lessen competitive interactions for space, and to assess the extent of temporal overlap. A one-way ANOVA comparing variation among sampling dates with inter-replicate variability at a given station was computed for each species. The F-ratio of among-group/within-group variance was used as an estimate of temporal vs. spatial variance. A highly significant F-ratio indicates a strong temporally varying component in population abundance. Patterns of temporal variation in abundance from one year to the next were compared for each species using Kendall's Coefficient of Concordance (Siegal, 1956). The ranks of seasonal densities were tested using all quarterly sampled stations within the study area. The average abundance rank for each species for each season was also calculated. This average rank was computed by first ranking seasonal abundances within a sampling year for a given species at each station. The ranks for each season were then summed and divided by the number of stations considered. Maximum abundances are ranked 1, minimum abundances are ranked 4 . Finally, graphical analysis of data was used to assess extent of temporal overlap.

\section{RESULTS}

\section{Physical Characteristics of the Study Area}

The stations sampled on the terrace atop the Tiger Scarp (Fig. 1), including the quarterly sampled Station $\mathrm{B} 4$, are characterized by coarse-skewed medium sands containing low organic carbon and silt-clay concentrations. Inferred sediment mobility (frequency of surficial sediment movement) is fairly high in this relatively shallow $(<52 \mathrm{~m})$ area. With increased depth to the east of the scarp, sediments grade from fineskewed medium sand on the flank to medium-fine sands in a broad swale $(\simeq 66 \mathrm{~m})$ referred to as the shallow swale. Associated with this swale are numerous patches, found primarily along its eastern margin, of highly mixed sediment which contain up to $6 \%$ silt and clay. These areas apparently represent erosional windows in which underlying Holocene clay deposits have been exposed and mixed with surficial sands (Stubblefield and Swift, 1976). The quarterly sampled Station B5 was located at a transition zone between shallow swale and eroded flank habitats. This was reflected in the temporally varying sediment characteristics found at this station.

A number of ridges covered by coarse-skewed medium sands traverse the study area. These are located at depths greater than the terrace to the west and are probably subjected to somewhat less frequent sediment disturbances. Within the study area these ridges grade into medium sand flanks as depth increases.

The deepest portion of the study area $(>70 \mathrm{~m})$ is a swale floored with fine sands with up to $8 \%$ silt and clay content. This deep swale constitutes a relatively quiescent environment subjected to infrequent bottom disturbance as a result of winter storm activity (Butman et al., 1979).

\section{Spatial Patterns in Species Distribution}

Grand mean (mean of quarterly means) abundances for each species at quarterly sampled stations provide preliminary evidence concerning species habitat requirements (Fig. 2). The corophiid Unciola irrorata, found throughout the study area, is common over much of the Middle Atlantic shelf (Boesch, 1979a). It reached maximum abundance at the shallow swale station (B5). The species was also abundant in ridge (B2), flank (B1), and deep swale (B3) habitats. In marked contrast, its congener $U$. inermis was relatively rare within the study area. It was abundant only at Station B5, particularly when collections at this station were from poorly sorted coarser sediments characteristic of eroded flanks. It was also occasionally found in high densities on the terrace (B4). Erichthonius rubricornis was most abundant at the shallow swale station B5 and, although it was found throughout the study area, its distribution was less even than that of $U$. irrorata. The ampeliscids Ampelisca vadorum and Byblis serrata were found primarily in the intermediate (ridge and flank) habitats. A. vadorum was most abundant at ridge station B2. Byblis serrata exhibited greatest abundance at flank station B1. Ampelisca aggassizi reached extremely high densities at the deep swale station B3, where it had an approximate density of one individual $\mathrm{cm}^{-2}$. Abundance levels were lower in the shallow swale (B5), but remained equal to or greater than the abundance of the other species.

Based on these data there appears to be little evidence suggesting habitat partitioning within the corophiid group. All 3 species reached maximum abundances at the shallow swale station. Conversely, some tendency towards spatial segregation is suggested for the ampeliscids with Ampelisca agassizi concentrated in deeper habitats with finer sediments 
while both $A$. vadorum and Byblis serrata were concentrated in the intermediate habitats.

\section{Classification and Multiple Discriminant Analysis}

Species distribution patterns were further resolved using abundance data and abiotic parameters measured at the 52 stations during November 1976. Results from classification analysis using flexible sorting produced six interpretable groups of stations (Table 1). The relative contribution of each species to site group definition, or conversely, the relative ability to define a set of stations within a group by the particular species present at those stations was estimated using the Fratio of among-groups to within-groups variations in abundance (Table 2).

Group II stations clearly represent the conditions most conducive to high densities of Ampelisca vadorum. Byblis serrata was most abundant at the stations in Group III, but was also fairly common at the stations in Groups II and V. A. agassizi was most abundant at the stations in Groups V and VI. Unciola inermis was found in high abundances only at the stations in Group IV. Erichthonius rubricornis was most abundant at the stations in Group V. U. irrorata had a low F-ratio and was not restricted to any particular group of stations although it reached maximum abundances at stations in Groups IV and V.

Analysis of environmental differences among groups which might account for the observed patterns in distribution and abundance of the six species was accomplished using multiple discriminant analysis. Abiotic parameters used in the analysis included depth, per-
Table 1. Site groups selected from numerical classification

\begin{tabular}{|cl|}
\hline Site group & \multicolumn{1}{c|}{ Stations included } \\
\hline I & B4, P1, P2, P3, P4, P5, P6, P7, P8, P9, P0 \\
II & D1, D2, D3, D4, D5, D7, R2, R4 \\
III & B1, B2, F1, F2, F3, F5, M4, M5, R5, R7, S4 \\
IV & M2, M3, R6, R9, S2, S7 \\
V & B5, F4, F6, M6, R1, R8, S1, S3, S5, S6 \\
VI & B3, D6, M1, R3, S8, S9 \\
\hline
\end{tabular}

cent gravel, percent coarse sand, percent medium sand, percent fine sand, percent silt and clay, total organic carbon content $\left(\mathrm{mg}^{-1} \mathrm{~g}\right)$, and sediment sorting coefficient $(\phi)$. Sediment percentages were transformed $(\arcsin \sqrt{p})$ to minimize non-linearity and improve normality. The raw data summary shows the untransformed mean values for each abiotic parameter for each group as well as the species most strongly associated with that set of stations (Table 3).

The overall chi-squared test of significance of among-group differences was highly significant $\left[\mathrm{X}^{2}=\right.$ $172.53,40$ d.f.]. This value is likely to be biased as a result of heterogeneity in within-groups variancecovariance matrices. Using the criteria outlined by Green (1971) it was decided that only the first 2 axes, which together account for $93 \%$ of the among-group variance, should be considered.

The orientation of groups in discriminant space is shown in Fig. 3. Pooled within-groups correlations between discriminating variables and discriminant functions were used to label vectors indicating the relative orientation of the most important parameters contributing to among-group separation on the first 2
Fig. 2. Grand mean (mean of quarterly means) abundances of each species in each habitat type represented by quarterly sampled stations (B1 flank; B2 ridge; B3 deep swale; B4 terrace; B5 shallow swale
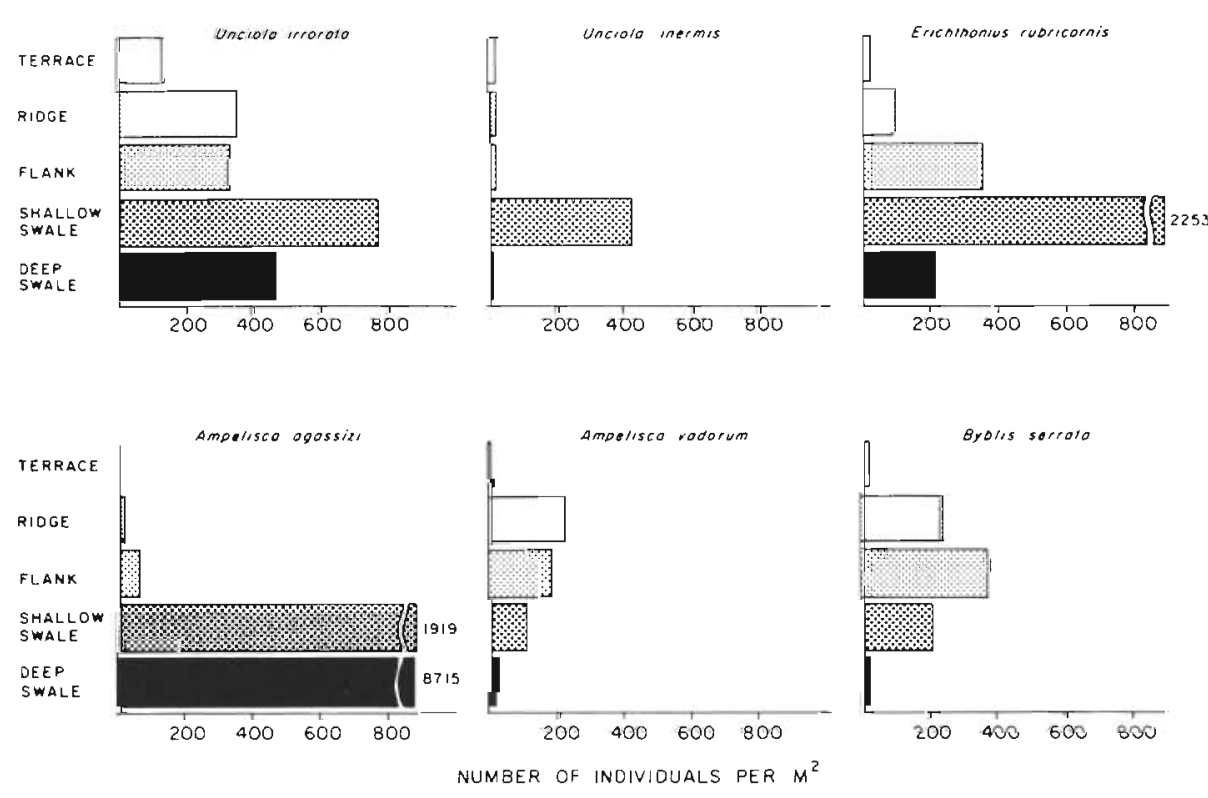
Table 2. F-ratios and geometric mean abundances (individuals $0.1 \mathrm{~m}^{-2}$ ) with $95 \%$ confidence limits in parentheses for each species at each site group. All ratios significant at 0.01 level $(5,46$ d. f.)

\begin{tabular}{|c|c|c|c|c|c|c|c|}
\hline \multirow[b]{2}{*}{ Species } & \multirow[b]{2}{*}{ F-ratio } & \multicolumn{5}{|c|}{ Geometric mean abundance (95\% C. L.) } & \multirow[b]{2}{*}{ VI } \\
\hline & & I & II & III & IV & $\mathrm{v}$ & \\
\hline $\begin{array}{l}\text { Ampelisca } \\
\text { vadorum }\end{array}$ & 10.42 & 0.00 & $\begin{array}{l}22.80 \\
(11.97,40.97)\end{array}$ & $\begin{array}{l}2.28 \\
(0.00,6.50)\end{array}$ & $\begin{array}{l}2.17 \\
(0.00,7.96)\end{array}$ & $\begin{array}{l}3.05 \\
(1.05,6.97)\end{array}$ & $\begin{array}{l}1.88 \\
(0.00,6.03)\end{array}$ \\
\hline $\begin{array}{l}\text { Ampelisca } \\
\text { agassizi }\end{array}$ & 56.40 & 0.00 & 0.00 & $\begin{array}{l}1.05 \\
(0.00,1.63)\end{array}$ & $\begin{array}{l}0.66 \\
(0.00,2.96)\end{array}$ & $\begin{array}{l}68.90 \\
(28.20,170.60)\end{array}$ & $\begin{array}{l}273.74 \\
(91.07,822.91)\end{array}$ \\
\hline $\begin{array}{l}\text { Byblis } \\
\text { serrata }\end{array}$ & 14.98 & $\begin{array}{l}0.39 \\
(0.00,0.96)\end{array}$ & $\begin{array}{l}11.44 \\
(4.32,30.30)\end{array}$ & $\begin{array}{l}29.19 \\
(15.46,55.12)\end{array}$ & $\begin{array}{l}5.24 \\
(0.00,24.26)\end{array}$ & $\begin{array}{l}9.97 \\
(4.71,21.08)\end{array}$ & $\begin{array}{l}1.22 \\
(0.00,4.03)\end{array}$ \\
\hline $\begin{array}{l}\text { Unciola } \\
\text { imrorata }\end{array}$ & 3.21 & $\begin{array}{l}11.19 \\
(7.94,15.64)\end{array}$ & $\begin{array}{l}6.49 \\
(2.62,14.50)\end{array}$ & $\begin{array}{l}18.79 \\
(7.63,44.31)\end{array}$ & $\begin{array}{l}32.54 \\
(13.63,77.72)\end{array}$ & $\begin{array}{l}26.00 \\
(16.71,40.46)\end{array}$ & $\begin{array}{l}17.09 \\
(10.51,27.77)\end{array}$ \\
\hline $\begin{array}{l}\text { Unciola } \\
\text { inermis }\end{array}$ & 22.03 & $\begin{array}{l}0.45 \\
(0.00,1.64)\end{array}$ & $\begin{array}{l}0.86 \\
(0.00,2.51)\end{array}$ & $\begin{array}{l}1.69 \\
(1.16,2.45)\end{array}$ & $\begin{array}{l}62.76 \\
(38.69,101.78)\end{array}$ & $\begin{array}{l}1.90 \\
(0.00,4.99\}\end{array}$ & $\begin{array}{l}0.90 \\
(0.00,3.25)\end{array}$ \\
\hline $\begin{array}{l}\text { Erichthonius } \\
\text { rubricornis }\end{array}$ & 9.48 & 0.00 & $\begin{array}{l}5.39 \\
(0.53,15.09)\end{array}$ & $\begin{array}{l}7.22 \\
(2.56,18.01)\end{array}$ & $\begin{array}{l}3.08 \\
(0.00,11.96)\end{array}$ & $\begin{array}{l}35.00 \\
(20.18,60.69)\end{array}$ & $\begin{array}{l}1.95 \\
(0.00,3.86)\end{array}$ \\
\hline
\end{tabular}

Table 3. Untransformed mean values of abiotic parameters for each group. Species most strongly associated with each group are indicated

\begin{tabular}{|c|c|c|c|c|c|c|c|c|c|}
\hline $\begin{array}{l}\text { Group/ } \\
\text { Principal } \\
\text { species }\end{array}$ & $\begin{array}{l}\text { Number } \\
\text { of stations } \\
\text { in group }\end{array}$ & $\begin{array}{l}\text { Depth } \\
\text { (m) }\end{array}$ & $\begin{array}{c}\% \\
\text { Gravel }\end{array}$ & $\begin{array}{c}\% \\
\text { Coarse } \\
\text { sand }\end{array}$ & $\begin{array}{c}\% \\
\text { Medium } \\
\text { sand }\end{array}$ & $\begin{array}{c}\% \\
\text { Fine } \\
\text { sand }\end{array}$ & $\begin{array}{c}\% \\
\text { Silt }+ \\
\text { clay }\end{array}$ & $\begin{array}{c}\text { Organic } \\
\mathrm{C} \\
\left(\mathrm{mg} \mathrm{g}^{-1}\right)\end{array}$ & $\begin{array}{c}\text { Sorting } \\
\text { coeff. } \\
(\varnothing)\end{array}$ \\
\hline $\begin{array}{l}\text { I } \\
\text { none }\end{array}$ & 11 & 43.6 & 4.98 & 29.21 & 60.69 & 4.94 & 0.19 & 0.36 & 0.64 \\
\hline $\begin{array}{l}\text { II } \\
\text { A. vadorum } \\
\text { B. serrata }\end{array}$ & 8 & 64.5 & 3.94 & 16.10 & 68.94 & 10.49 & 0.55 & 0.91 & 0.56 \\
\hline $\begin{array}{l}\text { III } \\
B . \text { serrata } \\
U . \text { irrorata }\end{array}$ & 11 & 60.0 & 3.22 & 22.23 & 54.38 & 18.21 & 1.62 & 0.64 & 0.67 \\
\hline $\begin{array}{l}\text { IV } \\
U . \text { inermis } \\
\text { U. irrorata }\end{array}$ & 6 & 63.1 & 12.15 & 21.63 & 49.82 & 13.40 & 3.35 & 0.97 & 0.89 \\
\hline $\begin{array}{l}\text { V } \\
\text { E. rubricornis } \\
\text { A. agassizi } \\
\text { U. irrorata }\end{array}$ & 10 & 64.2 & 2.77 & 5.93 & 51.78 & 35.30 & 3.84 & 1.22 & 0.48 \\
\hline $\begin{array}{l}\text { VI } \\
\text { A. agassizi }\end{array}$ & 6 & 69.8 & 2.82 & 3.05 & 27.31 & 60.75 & 4.95 & 1.71 & 0.53 \\
\hline
\end{tabular}

discriminant functions. Discriminant function (DF) I is related to changes in both depth and fine sand content in sediments. Deep stations with sediments consisting of much fine sand have the highest negative scores on this axis. Shallow stations with little fine sand have the highest positive scores. DF II separates medium sand habitats from the more extreme habitat types

Direct consideration of species abundance patterns in discriminant space was made by first standardizing all abundance values for a particular species by its maximum value and then plotting these in discriminant space. In Figs. 4 and 5 the encircled areas include all those stations at which a species reached abundance $\geq 25 \%$ of their maximum. There is a clear separation of Ampelisca aggassizi from the other ampeliscids in discriminant space (Fig. 4). The orientation of the line of separation suggests the importance of sediment factors related to fine sand content. The distributions of $A$. vadorum and Byblis serrata are poorly separated. B. serrata is distributed in shallow coarse habitats as well as in the more intermediate portions of discriminant space.

Within the corophiid family the distribution of Unciola inermis is completely overlapped by the dis- 


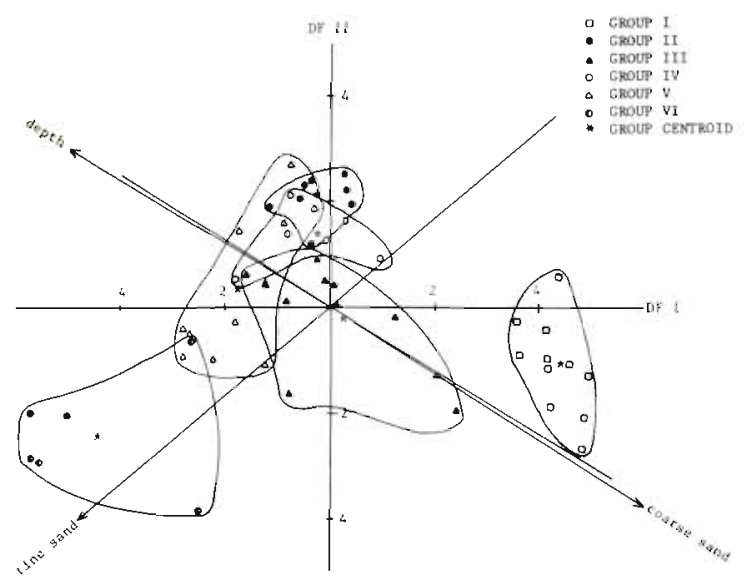

Fig. 3. Orientation of site groups in discriminant space. Vectors indicate relative orientation of important parameters contributing to among-group variance

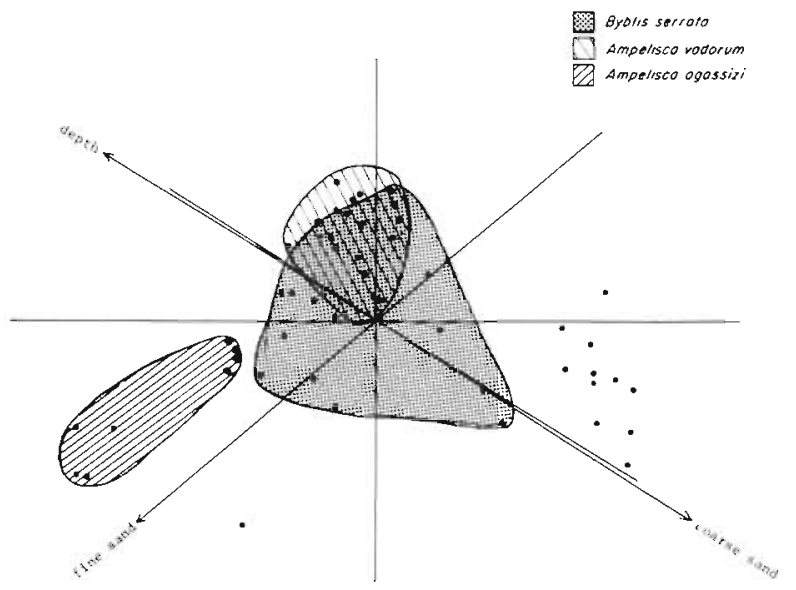

Fig. 4. Ampelisca agassizi, Ampelisca vadorum, and Byblis serrata. Standardized abundances in discriminant space. Shaded areas enclose all points at which species abundance were $\geq 25 \%$ of maximum

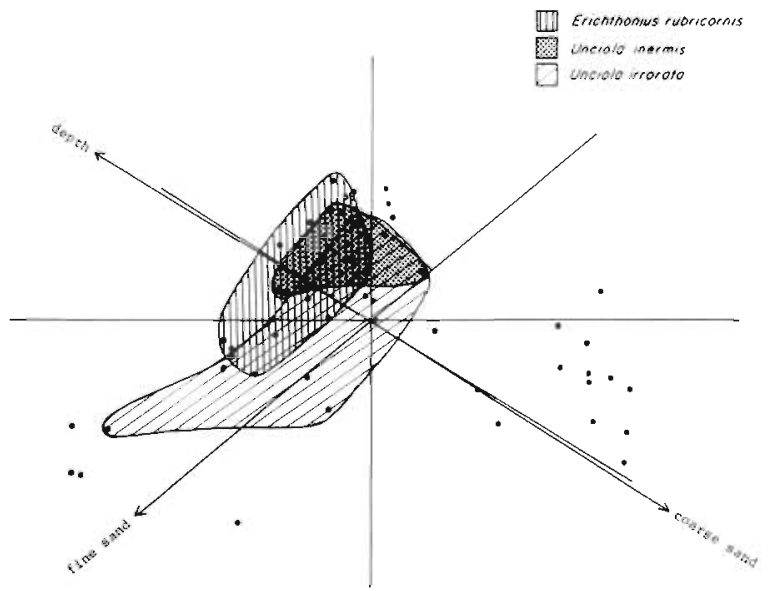

Fig. 5. Unciola irrorata, Unciola inermis and Erichthonius rubricornis. Standardized abundances in discriminant space. Shaded areas enclose all points at which species abundances were $\geq 25 \%$ of maximum tributions of the other 2 species (Fig. 5). Clear patterns of segregation are not observed in this group of amphipods. The only apparent cross-family pattern of spatial segregation concerns the absence of all species except Ampelisca agassizi and $U$. irrorata from the deepest, finest grained portions of the study area.

\section{Temporal Patterns in Abundance}

Temporal patterns in abundance for each species at each quarterly-sampled station are shown in Fig. 6. Erichthonius rubricornis was generally most abundant during spring and summer. Unciola irrorata frequently had maximum abundances during spring and to a certain extent during winter, particularly in 1977. Both of these species were least abundant in fall. Although low abundances of $U$. inermis at most stations made analysis of species abundance patterns difficult, the data suggest a trend toward maximum abundances during late spring and summer, with lowest abundances occurring in winter months. Spatial overlap of $U$. inermis with its congener, $U$. irrorata, might be lessened by these offset peaks in high population densities.

Patterns of temporal segregation are less apparent among the ampeliscids although slight shifts in peak abundance are suggested by the average rank of seasonal densities. Byblis serrata is the only species which was not most abundant during the spring and summer sampling periods.

The results of the Kendall's test of concordance were markedly different for species in the two families. All corophiids exhibited strongly concordant $(p<0.01$ ) seasonal trends in abundance among stations. The ampeliscids either remained relatively persistent over time (Ampelisca agassizi) or did not vary in a strongly concordant manner (Table 4). F-ratios, which were significant for all species at most stations, were generally higher for corophiid family members (Table 4).

\section{DISCUSSION}

\section{Spatial Patterns}

Patterns of distribution and abundance within the study area indicate a clear partitioning of habitats between Ampelisca agassizi and the other ampeliscids. The preference exhibited by Byblis serrata for shallow $(\leq 64 \mathrm{~m}$ ), fairly dynamic, medium sand habitats is supported by data from other areas of the Middle Atlantic Bight. Boesch $(1979 a$, b) commonly found $B$. serrata on the central shelf where sediments consisted of medium to medium-fine sands (median 
Table 4. Results of statistical analyses of temporal variability. n. s.: not significant

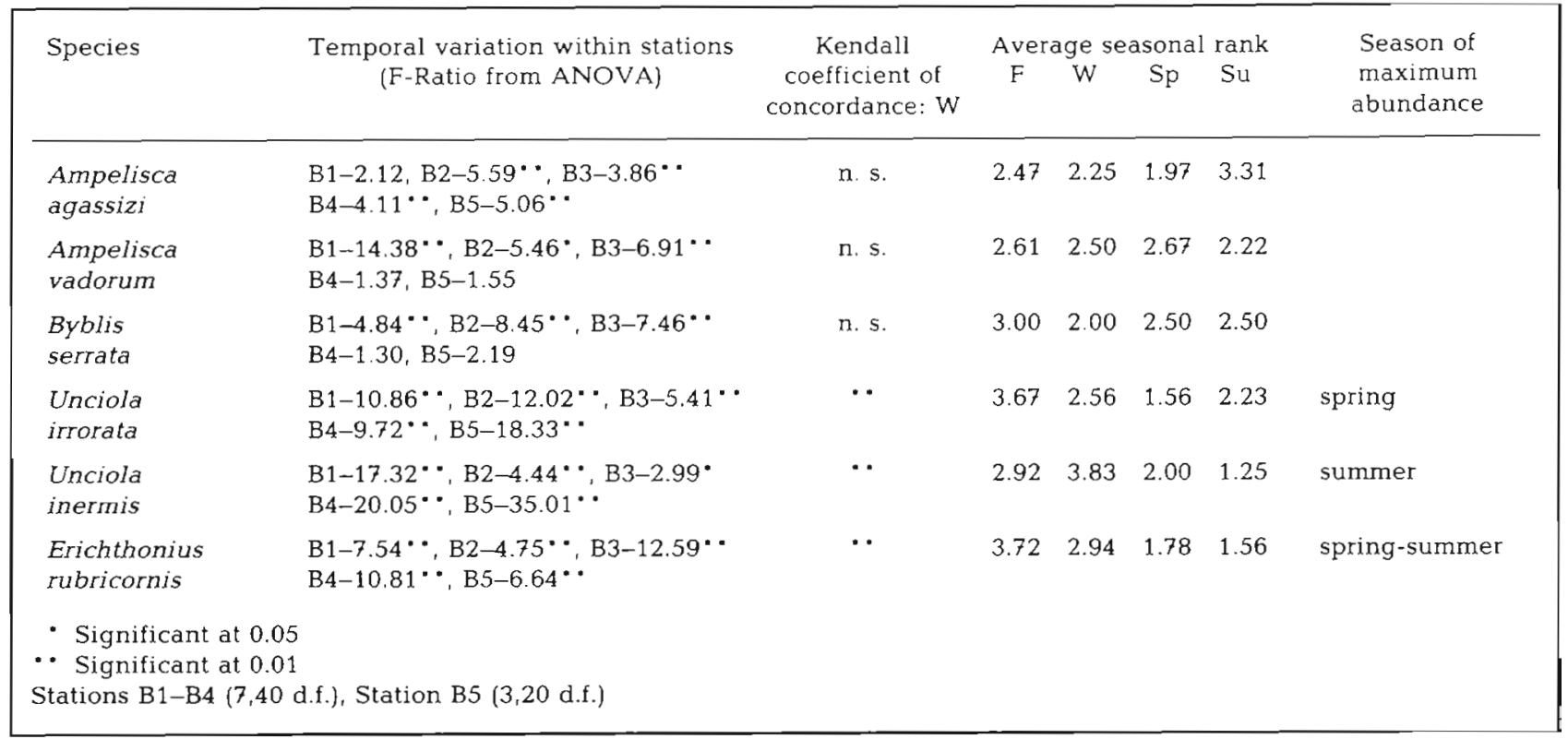

diameter 1.5 to $2.3 \phi$ ). Over the 5 yr period $1972-1977$ large populations of this species were found on medium-fine sands at approximately $30 \mathrm{~m}$ depths off the south shore of Long Island near Fire Island (Boesch et al., in press). Dickinson et al. (1980) found B. serrata to be most abundant at depths ranging from 20 to $29 \mathrm{~m}$. Bousfield (1973) indicates that the species is most frequent on medium to coarse sand.

The depth and sediment distribution preferences of Ampelisca vadorum as recorded in the literature are less well defined. In the Middle Atlantic Bight (Boesch, $1979 a$, b) the species was found over a wide depth range. It was both persistent and abundant on deep, clean, medium sand ridges and flanks near the shelf break where median sediment diameter ranged from 1.1 to 2.0 中. Similar distribution patterns were found in Area $B$ where $A$. vadorum was common on medium sand ridges at comparable depths. A. vadorum was also abundant in medium-fine sands (median diameter $2.25 \phi)$ at a central shelf swale. Although sediments in this swale contained up to $7.8 \%$ silt and clay (mean $=$ $5.3 \%$ ), A. agassizi was found only rarely. Biernbaum (1979) found $A$. vadorum on gravel, muddy sand and medium sand bottoms in Fishers Island Sound $(\simeq 30 \mathrm{~m})$ off Connecticut. Sanders (1956) and Mills (1967) report A. vadorum (= Species A, Sanders, 1956) from gravelly sands at 10 to $12 \mathrm{~m}$ depths in Long Island Sound. These data suggest that $A$. vadorum has relatively eurytopic depth and sediment requirements.

Conversely, Ampelisca agassizi may be characterized as a specialist exhibiting more stenotopic habitat requirements. The extremely high, persistent densities of this species in swales of the study area reflect similarly dense populations in comparable habitats (fine sands, 5 to $10 \%$ silt-clay, $\geqslant 60 \mathrm{~m}$ ) throughout the Middle Atlantic Bight. Pratt (pers. comm.) found this species in shallower $(35 \mathrm{~m})$ but sedimentologically similar habitats in Block Island Sound off Rhode Island. The shallow depth distribution of the species in that region may be related to local hydrographic conditions which result in greater bottom stability than would be experienced at comparable depths on the shelf off Long Island and New Jersey.

The relative absence of Ampelisca vadorum from outer shelf swale environments may reflect an inability to compete successfully for resources with $A$. agassizi rather than an inability to utilize deep, fine sediment habitats. As previously noted, $A$. vadorum is abundant at depths greater than $60 \mathrm{~m}$ on the outer shelf. Additionally, population densities of $A$. vadorum greater than or equal to those maintained within the study area were often found at central shelf swales (Boesch, 1979a). The granulometric conditions in these swales were similar to, or in some cases finer than, those in outer shelf swales. Thus, the abundance of $A$. vadorum in deep, fine-sediment habitats appears to be negatively related to the abundance of its congener $A$. agassizi.

Within the study area, populations of Ampelisca vadorum and Byblis serrata frequently co-occurred with all 3 species of corophiids. Yet, the only corophiid species to utilize successfully the deep swale habitat and, therefore, to coexist successfully with $A$. agassizi, was Unciola irrorata. This species is reportedly domicolous, but has lost the spinning glands present in other members of the Corophiidae (Bousfield, 1973). It 

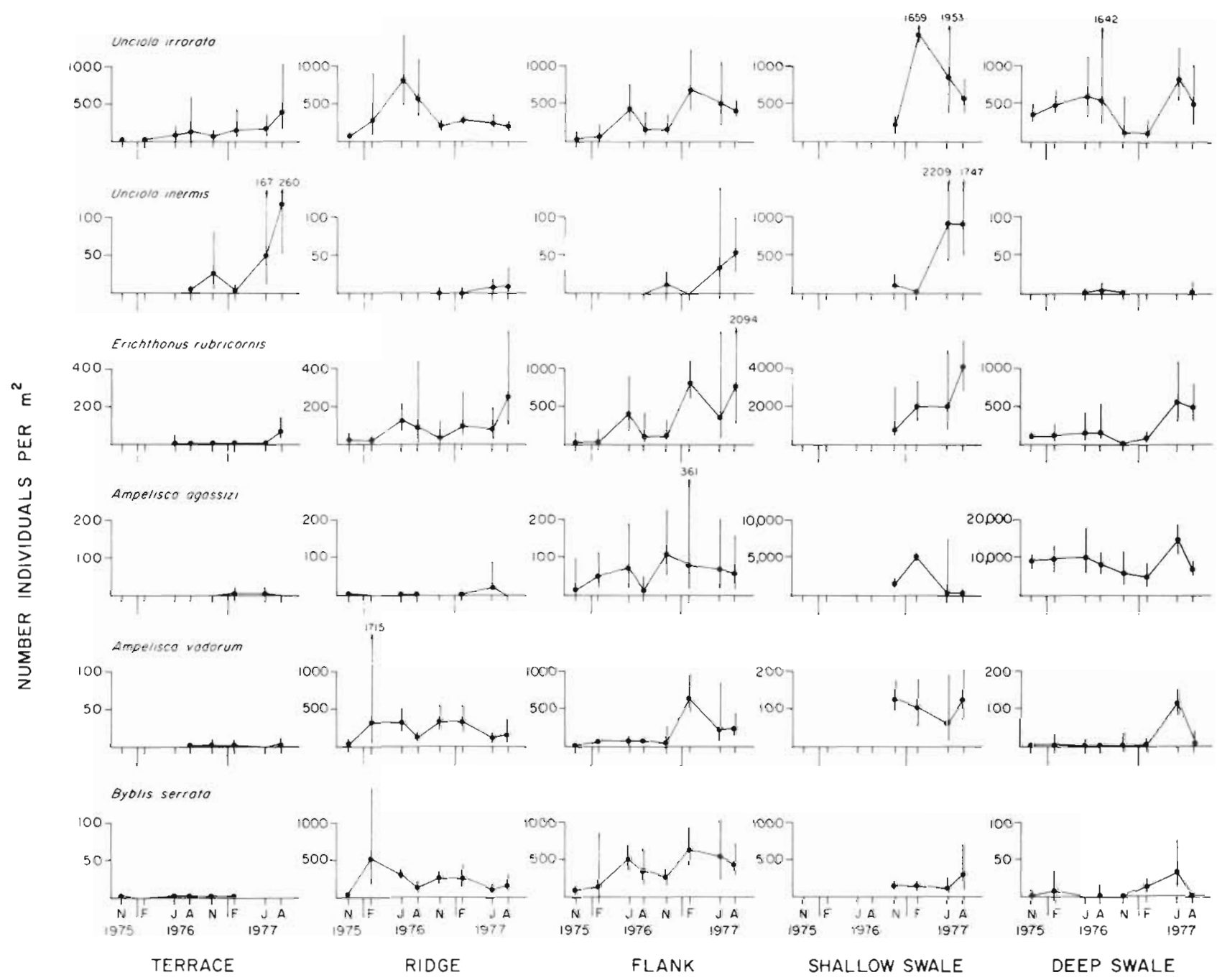

Fig. 6. Temporal patterns in geometric mean abundance exhibited by each species at each quarterly sampled station for period November 1975 to August 1977. Bars: $95 \%$ confidence limits

has occasionally been observed occupying the vacated tubes of other organisms such as the polychaete Prionospio (Feeley and Wass, 1971). The presence of $U$. irrorata in habitats supporting few tube dwellers, such as the terrace stations, suggests a facultative tube dwelling existence. In our laboratory, aquaria individuals of this species were capable of maintaining unlined burrows in the sediment and moving around freely on the sediment surface. Such mobility, in combination with facultative domicolous behavior presumably account for the widespread, relatively homogeneous distribution of the species across the shelf.

Unciola inermis was most commonly found on poorly sorted sediments which often contained large quantities of shell hash - evidence consistent with the species presence on shelly medium-fine sands (median diameter $1.77 \phi$ ) and medium-coarse sands (median diameter $1.21 \phi$ ) in the Hudson Shelf Valley region
(Boesch, 1979a, b). The topography of these environments suggests that they may be hydrodynamically erosional. It was particularly striking to note that nearly all of the stations at which the species occurred within the study area were located in a band along the eastern and southern flanks of the shallow swale. Dickinson et al. (1980) found $U$. inermis to be most abundant on sand-gravel bottoms between 30 and $59 \mathrm{~m}$ depths. The particular aspect of the physical environment to which this species responds is unknown. Close morphological similarities between $U$. inermis and the congeneric species, $U$. irrorata, have frequently led to confusion in identification of the 2 species (M. Bowen, pers. comm.; L. Watling, pers, comm.) and, consequently, a paucity of information on their ecology. The specialized habitat requirements of $U$. inermis as well as a strong similarity in the functional morphology of $U$. inermis - U. irrorata (Schaffner, 1980) suggest avoi- 
dance of extensive overlap in resource use through exploitation of different microhabitats rather than differential use of trophic resources

Although frequently coexisting with Ampelisca agassizi in the shallow swale habitat, Erichthonius rubricornis was generally low in abundance in the deepest portions of the study area. E. rubricornis, an epifaunal suspension-feeding species, may be excluded from these deep habitats by the close spacing of ampeliscid tubes or by the lack of other suitable attachment substrate. Alternatively, the relatively quiescent environment of deep swales may prevent effective suspension feeding.

\section{Temporal Changes in Population Abundances}

Temporal changes in abundance do not appear to play an important role in reducing potential resource competition among the species considered in this study. The spatially co-occurring populations of Ampelisca vadorum and Byblis serrata exhibited less temporal variability than they did inter-replicate variability (Fig. 6). Although the corophiids exhibited significant seasonal variations in abundance, temporal overlap in abundance among these species remained relatively high.

The lack of strong seasonal trends in population abundances is not surprising. Boesch (1979a) and Boesch et al. (in press) noted the relative persistence of the total outer shelf macrobenthic community of the Middle Atlantic Bight in comparison to the strong seasonal abundance patterns demonstrated by Frankenberg and Leiper (1977) for shallow shelf communities off Georgia or by Ziegelmeier $(1963,1970)$ for sand bottom macrobenthos of the German Bight. Additionally, monitoring at Station B3 (= Station 13, Northeast Monitoring Program, National Marine Fisheries Service) during the period April 1978 to the present by Reid et al. (unpubl.) has confirmed the continued persistence of the benthic community in this outer shelf swale. This relative seasonal persistence may be the result of a more constant thermal regime. The net flow of water on the Middle Atlantic continental shelf is toward the southwest. Cold bottom water, which may originate on the southern New England shelf or in the Gulf of Maine (Bumpus, 1973; Beardsley et al., 1976; Csanady, 1976), flows from the northeast as a discrete 'cold pool'. This cold water remains on the outer shelf during the summer, maintaining strong thermal stratification, thereby buffering the benthos from seasonal warming of surface waters. Thus, while seasonally variable bottom temperatures $\left(3\right.$ to $\left.20^{\circ} \mathrm{C}\right)$ are found on the inner shelf, bottom temperatures are relatively constant and colder $\left(4\right.$ to $\left.11^{\circ} \mathrm{C}\right)$ on the cen- tral and outer shelf (Walford and Wicklund, 1968; Colton and Stoddard, 1972).

\section{The Relative Importance of Resources}

Except where dense populations ( $>5000$ individuals $\mathrm{m}^{-2}$ ) of amphipods are found in topographic depressions the populations of amphipods in the study area do not appear to be limited by spatial resources. Average total densities for these 6 species in the ridge, flank, and terrace habitats ranged from 20 to 134 ind. $\mathrm{m}^{-2}$ (Fig. 2). These densities yield average potentially exploitable surface areas ranging between 75 and 500 $\mathrm{cm}^{2}$ ind. ${ }^{-1}$

Both Ampelisca vadorum and Byblis serrata occasionally exhibit greatly increased population densities on the shelf which cannot be explained by changes in sedimentary conditions. These increased densities have generally occurred in central shelf regions (Boesch, 1979a). Boesch et al. (in press) documented a series of population increases and decreases for $B$. serrata and other benthic species off southern Long Island. These temporal variations were apparently related to episodic enrichment of the overlying water column as a result of heavy phytoplankton blooms chiefly composed of the dinoflagellate Ceratium tripos. Elmgren (1978) has noted a similar phenomenon in the Baltic Sea where a threefold increase in the biomass of the amphipod Pontoporeia sp. occurred in response to the sedimentation of an intense phytoplankton bloom during the spring of 1972 . Populations of $A$. vadorum and $B$. serrata may be restricted, particularly on the outer shelf, to habitats in which trophic resources are limited. Dramatic increases in population abundances on the central shelf may reflect effective utilization of episodic resource enrichment.

\section{The Roles of Predation and Disturbance}

Although evidence exists which suggests that resource partitioning is occurring among the species investigated in this study the potential role of other structuring forces should be examined. Biotic interactions among these species are probably influenced by both predation and disturbance. These forces would presumably act to lower population densities, thereby decreasing the likelihood of interspecific interactions.

On the outer shelf the peracaridans, particularly Unciola irrorata and Erichthonius rubricornis, are of major importance in the diets of bottom feeding fishes and are consumed far out of proportion with their numbers in the infauna (Boesch, 1979a; Sedberry, 1980). The ampeliscids Ampelisca vadorum and Byblis 
serrata are generally of secondary importance to most fishes, but are consumed more frequently than $A$. agassizi which is important only in the diet of the scup (Stenotomus chrysops). The corophiid $U$. inermis has not been reported as a food item in the diet of any of the fishes examined, but this may reflect problems with taxonomic identity of the species

Zimmerman et al. (1979) noted that an amphipod guild within a seagrass bed of the Indian River, Florida appeared to be partitioning trophic resources although their abundances were known to be strongly limited by predation. He postulated that trophic partitioning may be a relic of competitive interactions in ancient or fluctuating environments where competition is intense for short time periods and may be occurring with enough regularity to maintain the selective advantage.

The lack of strong seasonal trends in amphipod population abundances as well as a year-round presence of important fish predators in this area of the shelf (Foell and Musick, 1979) suggests that the selective advantage of maintaining resource partitioning mechanisms is not facilitated on an annual basis. However, longer term changes in amphipod abundance on the shelf have been noted. Boesch (1979a) found that some species - principally Unciola spp., Ampelisca vadorum and Byblis serrata - were more abundant on the outer shelf during 1975-1977 than they were during 1974 when Radosh et al. (1978) sampled macrobenthos in the same area. Our more recent observations (unpubl.) suggest that year to year variation in stormgenerated disturbance of bottom sediments, primarily in the relatively shallow ridge and flank habitats, may also be important in regulating amphipod success and habitat distribution in this outer shelf region. During the summer of 1979 we found dense populations of amphipods (Erichthonius rubricornis, Unciola irrorata and Ampelisca vadorim) in a coarse-medium sand ridge habitat of Area $B$ in which they were much less common during 1975-1977. This was apparently related to a period of unusual bottom substrate stability which facilitated tube-building activities in an area where they would otherwise be eroded due to more dynamic conditions. Thus, one might hypothesize that resource partitioning mechanisms, such as those observed in this suite of species, would be of adaptive significance in facilitating coexistence and maintenance of community structure when intrinsic or extrinsic factors permit concordant rises in population abundances.

Acknowledgements. The authors would like to thank Dan Alongi, Bob Diaz, Tom Fredette and 3 anonymous reviewers for reading and commenting on the manuscript. Numerous discussions with the Benthic Ecology Group at VIMS proved helpful in clarifying ideas during the early stages of this study. M. Q. Bowen is thanked by the senior author for instructions in amphipod taxonomy and the general level of support she provided throughout this study. Portions of this study were supported by the U.S. Bureau of Land Management as part of the Middle Atlantic Outer Continental Shelf Environmental Studies Program under Contract No. AA550CT6-62. Drafts and final copy of this manuscript were prepared by the VIMS Report Center

\section{LITERATURE CITED}

Beardsley, R. C., Boicourt, W. C., Hansen, D. V (1976). Physical oceanography of the Middle Atlantic Bight. Am. Soc. Limnol. Oceanogr. Spec. Symp. 2: 20-34

Biernbaum, C. K. (1979). Influence of sedimentary factors on the distribution of benthic amphipods of Fishers Island Sound, Connecticut. J. exp. mar. Biol. Ecol. 38: 201-223

Boesch, D. F. (1977). Application of numerical classification in ecological investigations of water pollution. U.S. Environmental Protection Agency, Ecological Research Series, EPA-600/3-77-033: 1-114

Boesch, D. F. (1979a). Benthic ecological studies: macrobenthos. In: Middle Atlantic Outer Continental Shelf Environmental Studies, Volume IIB. Chemical and Biological Benchmark Studies. Prepared by the Virginia Institute of Marine Science, Gloucester Point, VA, under contract No. AA550-CT6-62 with the Bureau of Land Management, U.S. Department of Interior

Boesch, D. F. (1979b). Bottom sediments and sedimentary framework. In: Middle Atlantic Outer Continental Shelf Environmental Studies, Volume IIB. Chemical and Biological Benchmark Studies. Prepared by the Virginia Institute of Marine Science, Gloucester Point, VA, under contract No. AA550-CT6-62 with the Bureau of Land Management, U.S. Department of Interior

Boesch, D. F. (in press). Ecosystem consequences of alteration of benthic community structure and function in the New York Bight region. In: Mayer, G. F. (ed.) Ecological stress in the New York Bight: science and management. Estuarine Research Federation, Columbia, South Carolina

Boesch, D. F., Schaffner, L. C., Swartz, R. C., de Ben, W., Cole, F. A. (in press). The macrobenthos of the New York Bight: temporal patterns, NOAA OMPA. Technical Report

Bousfield, E. L. (1973). Shallow water gammaridean Amphipoda of New England, Comstock Publ. Ass., Cornell University Press, Ithaca, New York

Bumpus, D. F. (1973). A description of the circulation on the continental shelf of the east coast of the United States. Progr Oceanogr. 6: 111-157

Butman, B., Noble, M., Folger, D. W. (1979). Long term observations of bottom current and bottom sediment movement on the mid-Atlantic continental shelf. J. Geophys. Res. 84 (C3): $1187-1205$

Clifford, H. T., Stephenson, W. (1975). An introduction to numerical classification, Academic Press, New York

Colton, J, B., Stoddard, R. R. (1972). Average monthly sea water temperatures Nova Scotia to Long Island. Am. Geogr. Soc. Ser. Atlas Mar. Environ. Folio 21

Conell, J. H. (1961). The influence of interspecific competition and other factors on the distribution of the barnacle Chthamalus stellatus. Ecology 42: 710-723

Cooley, W. W., Lohnes, P. R. (1962). Multivariate procedures for the behavioral sciences, Willey, New York

Cooley, W W., Lohnes, P. R. (1971). Multivariate data analysis, Wiley, New York

Csanady, G. 'T (1976). Wind-driven and thermohaline circulation over the continental shelf. In: Manowitz, B. (ed.) 
Effects of energy-related activities on the Atlantic Continental Shelf. Conference at Brookhaven National Laboratories, 1975, pp. 31-47

Dayton, P. K. (1971).Competition, disturbance, and community organization. The provision and subsequent utilization of space in a rocky intertidal community. Ecol. Monogr. 41: $351-389$

Dickinson, J. J., Wigley, R. L., Bordeur, R. D., Brown-Leger, S. (1980). Distribution of gammaridean Amphipoda (Crustacea) in the Middle Atlantic Bight region. NOAA Technical Report NMFS SSRF-741

Duane, D. B., Field, M. E., Meisburger, E. R., Swift, D. J. P., Williams, J. S. (1972). Linear shoals on the Atlantic inner continental shelf, Florida to Long Island. In: Swift, D. J. P., Duane, D. B., Pilkey, O. H. (eds.) Shelf sediment transport: processes and pattern. Dowden, Hutchinson and Ross, Stroudsberg, Pa., pp. $477-498$

Edwards, R. L. (1976). Middle Atlantic fisheries: recent changes in populations and outlook. Soc. Limnol. Oceanogr. Spec. Symp. 2: 302-311

Elmgren, R. A. (1978). Structure and dynamics of Baltic benthic communities, with particular reference of the relationship between macro- and meiofauna. Kieler Meeresforsch. 4: 1-22

Feeley, J. B., Wass, M. L. (1971). The distribution and ecology of the Gammaridea (Crustacea: Amphipoda) of the lower Chesapeake estuaries. Spec. Pap. Mar. Sci., Virginia Inst. Mar. Sci., Gloucester Point

Foell, E., Musick, J. A. (1979). Community structure analysis of fishes. In: Middle Atlantic Outer Continental Shelf Environmental Studies, Volume IIC. Chemical and Biological Benchmark Studies. Prepared by the Virginia Institute of Marine Science, Gloucester Point, VA. under contract No. AA550-CT6-62 with the Bureau of Land Management, U.S. Department of the Interior

Frankenberg, D., Leiper. A. S. (1977). Seasonal cycles in benthic communities of the Georgia continental shelf. In: Coull, B. C. (ed.) Ecology of marine benthos. University of South Carolina Press, Columbia, South Carolina, pp. 338-398

Green, R. H. (1971). A multivariate statistical approach to the Hutchinsonian niche: bivalve molluscs of central Canada. Ecology 52 (4) : 543-556

Green, R. H., Vascotto, G. L. (1978). A method for the analysis of environmental factors controlling patterns of species composition in aquatic communities. Wat. Res. 12: $583-590$

Ivester, M. S. (1980). The distribution of meiobenthic copepods along a sediment gradient: factor and niche analyses. Bull. mar. Sci. 30: 634-64.5

Knebel, H. J., Spiker, E. (1977). Thickness and age of the surficial sand sheet, Baltimore Canyon Trough area. Am. Ass. Petrol. Geol. Bull. 61

Lubchenco, J., Menge, B. A. (1978). Community development and persistence in a low rocky intertidal zone. Ecol. Monogr 48: 67-94

Menge, B. A. (1972). Competition for food between two intertidal starfish species and its effect on body size and feeding. Ecology 53: 635-644

Menge, B. A., Sutherland, J. P. (1976). Species diversity gradients: synthesis of the roles of predation, competition and temporal heterogeneity. Am. Nat. 110: 351-369

Menge, J. L., Menge, B. A. (1974). Role of resource allocation, agression and spatial herogeneity in coexistence of two competing intertidal starfish. Ecol. Monogr. 44: 189-209

Milliman, J. D. (1973). Marine geology. In: Saila, S. B. (coord.) Coastal and Offshore Environmental Inventroy, Cape Hat- teras to Nantucket Shoals. Mar. Publ. Ser. 3, University of Rhode Island, Kingston, R. I., pp. 10-1-10-91

Mills, E. L. (1967). The biology of an ampeliscid amphipod crustacean sibling species pair. J Fish. Res. Bd Can. 24 (2): 305-355

Paine, R. T. (1966). Food web complexity and species diversity. Am. Nat. 100: 65-75

Paine, R. T. (1969). The Pisaster - Tegula interaction: prey patches, predator food and intertidal community structure. Ecology 50: 950-961

Paine, R. T (1974). Intertidal community structure. Experimental studies on the relationship between a dominant competitor and its principal predator. Oecologia (Berl.) 15: 93-120

Peterson, C. H. (1979). Predation, competitive exclusion and diversity in the soft-sediment benthic communities of estuaries and lagoons. In: Livingston, R. J. (ed.) Ecological processes in coastal and marine systems. Plenum Press, New York, pp. 233-264

Radosh, D. J., Frame, A., Wilhelm, T. E., Reid, R. (1978). Benthic survey of the Baltimore Canyon Trough, May 1974. NOAA, Sandy Hook Laboratory Report No. SHL $78-8$

Rao, C. R. (1952). Advanced statistical methods in biometrical research, Wiley, New York

Sanders, H. L. (1956). Oceanography of Long Island Sound 1952-1954. X. The biology of marine bottom communities. Bull. Bingham Oceanogr. Coll. 15: 345-414

Schaffner, L. C. (in prep.). Functional morphology and trophic resource use of Ampeliscidae and Corophiidae from the Middle Atlantic Bight Outer Continental Shelf

Schaffner, L. C. (1980). Resource use by Amphipoda (Crustacea: Peracarida) on the outer continental shelf of the Middle Atlantic Bight: implications to community structure. Masters thesis, College of William and Mary, Williamsburg, Virginia

Schoener, T. W. (1974). Resource partitioning in ecological communities. Science, N. Y. 185: 27-39

Sedberry, G. R. (1980). Food habits, prey selectivity and food resource partitioning of a community of fishes on the outer continental shelf. Ph. D. dissertation College of William and Mary, Williamsburg, Virginia

Siegal, S. (1956). Non-parametric statistics for the behavioral sciences, McGraw-Hill, New York

Stimson, J. (1970). Territorial behavior of the owl limpet Lottia gigantea. Ecology 51: 113-118

Stubblefield, W. L., Lavelle, J. W., McKinney, T F., Swift, D. J. P. (1975). Sediment response to the present hydraulic regime on the central New Jersey shelf. J. Sediment. Petrol. 45: 337-358

Stubblefield, W. L., Swift, D. J. P. (1976). Ridge development as revealed by sub-bottom profiles on the central New Jersey shelf. Mar Geol. 20: 315-334

Swift, D. J. P. (1975). Tidal sand ridges and shoal retreat massif. Mar Geol. 18: 105-134

Swift, D. J. P., Kofoed, J. W., Saulsbury, F. P., Sears, P. (1972). Holocene evolution of the shelf surface, central and southern Atlantic shelf of North America. In: Swift, D. J. P., Duane, D. B., Pilkey, O. H. (eds.) Shelf sediment transport: processes and pattern. Dowden, Hutchinson and Ross. Stroudsburg, Pa., pp. 499-473

Walford, L. A., Wicklund, R. I. (1968). Monthly sea temperature structure from the Florida Keys to Cape Cod. Geogr Soc. Ser. Atlas Mar Environ. Folio 15

Whitlatch, R. B. (1980). Patterns of resource utilization and coexistence in marine intertidal deposit-feeding communities. J. mar Res. 38: 743-765 
Woodin, S. A. (1974). Polychaete abundance patterns in a marine soft sediment environment: the importance of biological interactions. Ecol. Monogr. 44: 171-187

Ziegelmeier, E. (1963). Das Macrobenthos im Ostteil der Deutschen Bucht nach qualitativen und quantitativen Bodengreiferuntersuchungen in der Zeit von 1949-1960. Veröff. Inst. Meeresforsch. Bremerh. 1 (Sonderbd.) (3 Meeresbiol. Symposium): 101-114
Ziegelmeier, E. (1970). Über Massenvorkommen verschiedener makrobenthaler Wirbelloser während der Wiederbesiedlungsphase nach Schädigungen durch 'katastrophale' Umwelteinflüsse. Helgoländer wiss. Meeresunters. 21. 9-20

Zimmerman, R., Gibson, R., Harrington, J (1979). Herbivory and detritivory among gammaridean amphipods from a Florida seagrass community. Mar Biol. 54: 41-47

This paper was submitted to the editor; it was accepted for printing on May 14, 1982 